\title{
Fertilizer rates and yield and quality of grass hays in southern Puerto Rico'
}

\author{
Rafael Ramos-Santana ${ }^{2}$ and Lee R. McDowell ${ }^{3}$
}

J. Agric. Univ. P.R. 82(1-2):17-24 (1998)

ABSTRACT

The mean dry matter yield (DMY), in vitro organic matter digestibility (IVOMD), crude protein (CP) content, and mineral concentrations of hays from four tropical grasses, each receiving four fertilizer levels, were studied at the Agricultural Experiment Station at Juana Diaz in the semiarid southern region of Puerto Rico. Significant $(P=0.05)$ differences in the mean DMY were observed among the grasses receiving the four fertilizer levels during all periods studied. Total DMY of the Cynodon dactylon cultivar, PRPI 11504, was superior to that of the Digitaria eriantha and two Digitaria decumbens cultivars under evaluation. Fertilizer level had little effect on the levels of trace elements, phosphorus and magnesium content of hays, but hay $C P$, calcium, sodium and potassium content were significantly $(P=0.05)$ affected by the level of fertilization. An increase in the rate of fertilizer was always followed by a decrease in the iron content.

Key words: grass hay, fertilization, Cynodon dactylon, Digitaria eriantha, Digitaria decumbens

\section{RESUMEN}

Niveles de fertilización y el rendimiento y calidad del heno de gramineas en el sur de Puerto Rico

Se estudió el rendimiento promedio de materia seca (MS), la digestibilidad in vitro de la materia orgánica (IVOMD), el contenido en proteina cruda (PC) y la concentración mineral del heno de cuatro gramíneas a cuatro niveles de fertilización en la Estación Experimental Agrícola de Juana Díaz en la región sur semiárida de Puerto Rico. Se obtuvieron diferencias significativas $(P=0.05)$ en el rendimiento de materia seca $(M S)$ entre los cuatro niveles de fertilización en todos los periodos. El rendimiento total de MS en Cynodon dactylon PRPI 11504 resultó significativamente $(P=0.05)$ superior a las otras variedades bajo evaluación. El nivel de fertilización tuvo poco efecto sobre el contenido promedio de elementos trazas, fósforo y magnesio del heno de las cuatro gramíneas estudiadas. El aumento en el nivel de fertilización produjo una reducción en el contenido de hierro. Los contenidos del PC, calcio, sodio y potasio en el heno se afectaron significativamente $(P=0.05)$ con el nivel de fertilización.

\section{INTRODUCTION}

In Puerto Rico, numerous studies have been conducted with chemical fractions such as neutral detergent fiber, acid detergent fiber and

'Manuscript submitted to the Editorial Board 29 January 1996.

${ }^{2}$ Associate Researcher, Department of Agronomy and Soils, University of Puerto Rico. "Professor, Department of Animal Sciences, University of Florida, Gainesville. 
CP content for determining hay quality standards (Arroyo-Aguilú and Oporta-Téllez, 1980; Gutierrez-Vargas et al., 1978; Méndez Cruz et al., 1988; Randel and Méndez-Cruz, 1989). Up to now, however, no research has been conducted in Puerto Rico on mineral fractions in the determination of hay quality standards. Minerals are an important part of hay chemical composition in ruminant nutrition. The lack or imbalance of the minerals also limits the performance of livestock (McDowell, 1985).

The objective of this study was to compare the DMY, IVOMD, CP content and mineral concentrations of four tropical forage grass cultivars as affected by the application of four fertilization rates in the semiarid southern region of Puerto Rico.

\section{MATERIALS AND METHODS}

Hay was made from four grass cultivars; Cynodon dactylon L. pers. PRPI 11504; Digitaria eriantha (PRPI: 5277); Digitaria decumbens stent. PRPI 6439; and Digitaria decumbens stent. PRPI 0560 (common pangola). Each cultivar was evaluated at the Fortuna Agricultural Experiment Station of the University of Puerto Rico in Juana Díaz between 15 April 1990 and 25 March 1992. The fertilizer formula 15-510 was evaluated at the following rates: very low $(561 \mathrm{~kg} / \mathrm{ha})$, low $(1,121 \mathrm{~kg} / \mathrm{ha})$, medium $(2,243 \mathrm{~kg} / \mathrm{ha})$ and high $(3,364 \mathrm{~kg} / \mathrm{ha})$. A San Antón soil (Cumulic Haplustolls) with $\mathrm{pH}$ of 8.03 was used for the evaluation. Average soil $\mathrm{P}, \mathrm{K}, \mathrm{Ca}$ and $\mathrm{Mg}$ were $17 \mathrm{mg} / \mathrm{kg}, 1.01 \mathrm{cmol} / \mathrm{kg}$; $24.55 \mathrm{cmol} / \mathrm{cg}$ and $3.50 \mathrm{cmol} / \mathrm{kg}$, respectively. The grasses were cut every 49 days during the above mentioned periods, and hay was harvested after 2.5 days of field drying. Irrigation was applied at the rate of $50 \mathrm{~mm}$ every week. The cuts of 21 November 1990 and 15 April 1991 were used to test the hay IVOMD, CP and mineral concentration. The treatments were arranged in a split-plot design with three replications. The grass cultivars were the main plots $\left(4.27 \times 10.36 \mathrm{~m}^{2}\right)$ and the four fertilizer levels the sub plots $\left(1.52 \times 4.57 \mathrm{~m}^{2}\right)$. Duncan's multiple range test at the probability level of $5 \%$, was used for the separation of means in each period.

Forage samples were dried at $55^{\circ} \mathrm{C}$ for one week and analyzed for micro and macro elements according to the methods of Fick et al., (1979). The determinations of $\mathrm{Cu}, \mathrm{Fe}, \mathrm{Mn}, \mathrm{Zn}, \mathrm{Ca}, \mathrm{K}, \mathrm{Mg}$ and $\mathrm{Na}$ content were made by atomic absorption spectrophotometry (PerkinElmer Corp, 1992)4. Crude protein and phosphorus content were deter-

\footnotetext{
"Trade names in this publication are used only to provide specific information. Mention of a trade name does not constitute a warranty of equipment or materials by the $\mathrm{Ag}$. ricultural Experiment Station of the University of Puerto Rico, nor is this mention a statement of preference over other equipment or materials.
} 
mined by a procedure developed by Gallaher et al. (1975) using the Technicon Industrial Systems (1978). Forage IVOMD was determined by a two-stage method as modified by Moore and Mott (1974). Cobalt and molybdenum content were determined by flameless atomic absorption spectrophotometry (Perkin-Elmer Corp., 1984) and selenium by a modified fluorimetric technique (Whetter and Ullrey, 1978). Standard reference material (SRM 1572, citxus leaves) from the National Institute of Standards and Technology (NIST) was included as an internal standard for all forage samples analyzed for mineral content.

\section{RESULTS AND DISCUSSION}

Significant differences were observed in DMY for the fertilization rates and cultivar yields over the three time periods (Tables 1 and 2). A significant interaction between variables was observed during 19901991. However, this interaction occurred neither in 1991-1992 nor in the total yield of both years.

The mean DMY for years 1990-1992 was 51\% higher with the high fertilization level than with the medium level (Table 1). With the medium level, DMY was $57 \%$ higher than with the low level. With the low level, the DMY was 35\% higher than with the very low level. A significant increase in DMY was obtained with each increase in the fertilization level for the mean of the four grasses under evaluation.

For all four fertilizer levels, the mean DMY of the Cynodon dactylon cultivar was significantly superior to the yield of the three Digitaria cultivars in all the periods of evaluation. No significant differences were observed among Digitaria cultivars with the exception of that of the 1990-1991 Digitaria decumbens (PRPI: 0560), whose DMY was inferior to that of the other cultivars (Table 2).

TABLE 1.-Mean annual dry matter yield $(\mathrm{kg} / \mathrm{ha})$ per fertilizer level of hays from four tropical forage grasses.

\begin{tabular}{lllll}
\hline & \multicolumn{4}{c}{ Levels of fertilization' } \\
\cline { 2 - 5 } Harvest period & High & Medium & Low & Very Low \\
\hline $1990-1991$ & $23,428 \mathrm{a}^{2}$ & $16,758 \mathrm{~b}$ & $10,611 \mathrm{c}$ & $8,486 \mathrm{~d}$ \\
$1991-1992$ & $29,520 \mathrm{a}$ & $18,385 \mathrm{~b}$ & $11,728 \mathrm{c}$ & $8,083 \mathrm{~d}$ \\
Mean & 26,474 & 17,571 & 11,169 & 8,284 \\
\hline
\end{tabular}

Fertilizer application rates (kg/ha) of a commercial 15-5-10 fertilizer were: high $(3,364)$; medium $(2,243)$; low $(1,121)$ and very low $(561)$.

2Means in the same rows followed by different letters differ $(\mathrm{P}<0.05)$. 
TABLE 2. - Mean annual dry matter yield ( $\mathrm{kg} / \mathrm{ha}$ ) of hays from four grass cultivars at four fertilizer levels.

\begin{tabular}{lllll}
\hline & \multicolumn{4}{c}{ Cultivars (PRPI) } \\
\cline { 2 - 5 } Harvest period & 11504 & 5277 & 6439 & \multicolumn{1}{c}{0560} \\
\hline $1990-1991$ & $19,340 \mathrm{a}^{2}$ & $14,148 \mathrm{~b}$ & $14,148 \mathrm{~b}$ & $12,279 \mathrm{c}$ \\
$1991-1992$ & $19,851 \mathrm{a}$ & $17,107 \mathrm{ab}$ & $16,529 \mathrm{ab}$ & $14,256 \mathrm{~b}$ \\
Mean & 19,595 & 15,627 & 15,338 & 13,267 \\
\hline
\end{tabular}

'Means in the same rows followed by different letters differ $(\mathrm{P}<0.05)$.

In relation to the IVOMD and ash content, no significant differences were observed among the four fertilizer levels in either season (Table 3). The CP content was significantly higher with the highest fertilizer level than with the very low fertilizer level in both seasons. In the short-day season, the mean $\mathrm{CP}$ content of all hays at all fertilizer levels was below the suggested critical concentration of $7.0 \%$ (Minson, 1971). Hay calcium concentration in both seasons decreased with increase in fertilizer level. This finding could be attributed to a dilution effect brought on by increasing the DMY at the higher application rates. In both seasons, a significant difference in calcium content was observed between the high and very low fertilizer levels. Mean calcium content for all fertilizer applications in both seasons was above beef cattle mineral requirements (McDowell, 1985; McDowell et al., 1993; NRC, 1984) with the exception of that of the high fertilizer level in the long day season.

The potassium and sodium concentrations resulting from each fertilizer treatment were above the requirements for beef cattle (McDowell, 1985; McDowell et al., 1993; NRC, 1984) for both seasons. No significant differences were observed in potassium and sodium concentrations between the high and medium fertilizer levels in either season. However, there were significant differences in the concentrations at these levels as compared to their concentrations at the two lower levels (Table 3). Potassium and sodium concentrations increased with the two higher fertilizer applications.

The concentration of phosphorus was always above the requirements for beef cattle (McDowell, 1985; NRC, 1984) and no significant differences in this element were observed among the four levels of fertilization during the short day season. Magnesium concentrations were always below the requirements for beef cattle (McDowell, 1985; NRC, 1984). These concentrations were not affected by the level of fertilization in the short day season. However, a significant difference in magnesium concentration was observed between the very low and high fertilizer levels during the long day season (Table 3). 
TABLE 3.-Mean percentage of IVOMD, CP, ash, and macroelement content of two cuttings of hay from four tropical forage grasses receiving four fertilization levels. ${ }^{1}$

\begin{tabular}{|c|c|c|c|c|c|c|c|c|c|c|c|c|c|c|c|c|}
\hline \multirow[b]{2}{*}{ Fertilization level } & \multicolumn{8}{|c|}{$\begin{array}{l}\text { Short day season } \\
21 \text { November } 1990\end{array}$} & \multicolumn{8}{|c|}{$\begin{array}{l}\text { Long day season } \\
15 \text { April } 1991\end{array}$} \\
\hline & IVOMD & $\mathrm{CP}$ & Ash & $P$ & $\mathrm{Ca}$ & K & $\mathrm{Mg}$ & $\mathrm{Na}$ & IVOMD & $\mathrm{CP}$ & Ash & $\mathrm{P}$ & $\mathrm{Ca}$ & $\mathrm{K}$ & $\mathrm{Mg}$ & $\mathrm{Na}$ \\
\hline $\mathrm{High}^{2}$ & $49.0 \mathrm{a}^{3}$ & $6.8 \mathrm{a}$ & $10.4 a$ & $0.31 \mathrm{a}$ & $0.30 \mathrm{~b}$ & $1.29 a$ & $0.10 \mathrm{a}$ & $0.31 \mathrm{a}$ & $48.4 a$ & $7.9 a$ & $10.1 \mathrm{~b}$ & $0.34 \mathrm{c}$ & $0.23 c$ & $1.76 \mathrm{a}$ & $0.08 \mathrm{~b}$ & $0.39 a$ \\
\hline Medium & $49.5 a$ & $6.5 \mathrm{ab}$ & $11.0 \mathrm{a}$ & $0.31 \mathrm{a}$ & $0.37 \mathrm{ab}$ & $1.29 \mathrm{a}$ & $0.11 \mathrm{a}$ & $0.27 a$ & $50.7 \mathrm{a}$ & $7.9 a$ & $10.6 \mathrm{~b}$ & $0.40 \mathrm{~b}$ & $0.36 \mathrm{~b}$ & $1.67 a$ & $0.11 \mathrm{ab}$ & $0.35 a$ \\
\hline Low & $49.6 \mathrm{a}$ & $6.5 \mathrm{ab}$ & $11.5 a$ & $0.34 \mathrm{a}$ & $0.39 a$ & $0.86 \mathrm{~b}$ & $0.10 a$ & $0.19 \mathrm{~b}$ & $52.3 \mathrm{a}$ & $7.4 \mathrm{ab}$ & $10.7 \mathrm{ab}$ & $0.44 a$ & $0.40 \mathrm{~b}$ & $1.40 \mathrm{~b}$ & $0.11 \mathrm{ab}$ & $0.29 \mathrm{~b}$ \\
\hline Very Low & $49.4 \mathrm{a}$ & $6.3 \mathrm{~b}$ & $11.5 a$ & $0.32 \mathrm{a}$ & $0.44 a$ & $0.86 \mathrm{~b}$ & $0.11 \mathrm{a}$ & $0.18 \mathrm{~b}$ & $50.9 a$ & $7.1 b$ & $11.3 a$ & $0.43 \mathrm{ab}$ & $0.67 a$ & $1.27 \mathrm{~b}$ & $0.17 \mathrm{a}$ & $0.23 c$ \\
\hline Mean & 49.4 & 6.5 & 11.1 & 0.32 & 0.37 & 1.10 & 0.10 & 0.24 & 50.6 & 7.6 & 10.67 & 0.40 & 0.41 & 1.52 & 0.12 & 0.31 \\
\hline $\mathrm{MER}^{4}$ & - & 7.0 & - & 0.25 & 0.30 & 0.60 & 0.18 & 0.08 & - & 7.0 & - & 0.25 & 0.30 & 0.60 & 0.18 & 0.08 \\
\hline
\end{tabular}

1Fall (21 November 1990) and spring (15 April 1991) means from two cuttings.

Application rates $(\mathrm{kg} / \mathrm{ha})$ of a commercial 15-5-10 fertilizer were as follows very low (561), low (1,121), medium (2,243) and high (3,364)

${ }^{3}$ Means in the same column followed by the same letters do not differ at $\mathrm{P}<0.05$.

${ }^{4}$ Critical concentrations or mineral element requirements for beef cattle (McDowell, 1985; McDowell et al., 1993; NRC, 1984). 
TABLE 4.-Mean microelement content ( $\mathrm{mg} / \mathrm{kg}$ ) of two hay cuttings from four tropical forage grasses receiving four fertilization levels.'

\begin{tabular}{|c|c|c|c|c|c|c|c|c|c|c|c|c|c|c|}
\hline \multirow{2}{*}{$\begin{array}{l}\text { Fertilization } \\
\text { level }\end{array}$} & \multicolumn{7}{|c|}{$\begin{array}{c}\text { Short day season } \\
21 \text { November } 1990\end{array}$} & \multicolumn{7}{|c|}{$\begin{array}{l}\text { Long day season } \\
15 \text { April } 1991\end{array}$} \\
\hline & $\mathrm{Cu}$ & $\mathrm{Zn}$ & $\mathrm{Mn}$ & $\mathrm{Fe}$ & Co & Mo & $\mathrm{Se}$ & $\mathrm{Cu}$ & $\mathrm{Zn}$ & $\mathrm{Mn}$ & $\mathrm{Fe}$ & Co & Mo & $\mathrm{Se}$ \\
\hline High"2 & $2.7 \mathrm{a}^{3}$ & $15.2 \mathrm{a}$ & $61.6 \mathrm{a}$ & $698 \mathrm{a}$ & $0.05 a$ & $0.40 \mathrm{a}$ & $0.07 a$ & $1.2 \mathrm{a}$ & $12.4 \mathrm{~b}$ & $45.0 \mathrm{a}$ & $98 b$ & $0.04 \mathrm{ab}$ & $0.22 c$ & $0.08 a$ \\
\hline Medium & $2.7 \mathrm{a}$ & $14.3 \mathrm{a}$ & $59.5 \mathrm{a}$ & $788 \mathrm{a}$ & $0.07 a$ & $0.27 \mathrm{a}$ & $0.06 \mathrm{a}$ & $1.5 a$ & $14.2 \mathrm{~b}$ & $42.7 \mathrm{a}$ & $133 b$ & $0.01 b$ & $0.34 b c$ & $0.08 \mathrm{a}$ \\
\hline Low & $2.5 \mathrm{a}$ & $13.4 \mathrm{a}$ & $54.0 \mathrm{a}$ & $942 a$ & $0.06 \mathrm{a}$ & $0.33 \mathrm{ab}$ & $0.16 \mathrm{a}$ & $1.4 \mathrm{a}$ & $18.9 \mathrm{a}$ & $40.6 a$ & $211 \mathrm{~b}$ & $0.05 \mathrm{~b}$ & $0.50 \mathrm{ab}$ & $0.07 a$ \\
\hline Very Low & $2.5 \mathrm{a}$ & $16.3 \mathrm{a}$ & $51.5 \mathrm{a}$ & $1068 \mathrm{a}$ & $0.08 \mathrm{a}$ & $0.35 a b$ & $0.09 a$ & $1.6 \mathrm{a}$ & $21.1 \mathrm{a}$ & 47.32 & $417 \mathrm{a}$ & $0.08 \mathrm{a}$ & $0.66 a$ & $0.09 a$ \\
\hline Mean & 2.6 & 14.8 & 56.7 & 874 & 0.06 & 0.34 & 0.09 & 1.4 & 16.7 & 43.9 & 215 & 0.04 & 0.43 & 0.08 \\
\hline $\mathrm{MER}^{4}$ & 8.0 & 30.0 & 40.0 & 50 & 0.10 & $3.0^{5}$ & 0.20 & 8.0 & 30.0 & 40.0 & 50 & 0.10 & 3.0 & 0.20 \\
\hline
\end{tabular}

IMean from cutting, fall (21 November 1990) and spring (15 April 1991).

${ }^{2}$ Fertilizer application rate ( $\left.\mathrm{kg} / \mathrm{ha}\right)$ of a commercial $15-5-10$ fertilizer were as follows: very low $(561)$, low (1,12] ', medium $(2,243)$ and high $(3,364)$.

${ }^{3} \mathrm{Means}$ in the same columns followed by the same letters do not differ $(\mathrm{P}<0.05)$. No differences $(\mathrm{P}>0.05)$ bctwcen cutting by fertilizer level interaction were found.

${ }^{4}$ Mineral element requirements or critical concentration (McDowell, 1985; McDowell et a]., 1993; NRC, 1984).

${ }^{5} \mathrm{Molybdenum}$ above $3 \mathrm{mg} / \mathrm{kg}$ is considered an excess level. 
The fertilizer application rate had little influence on forage copper and selenium concentrations. The zinc and cobalt hay concentrations were similar, except that the zinc levels were lower for the two highest fertilizer rates and cobalt was lower for the medium fertilizer rate during the long day season (Table 4).

The concentrations of copper, zinc, cobalt and selenium were below the requirements (McDowell, 1985; McDowell et al., 1993) for grazing cattle. The mean iron forage level of $874 \mathrm{mg} / \mathrm{kg}$ was extremely high in relation to the mineral element requirement for grazing cattle. Also the iron content decreased with each increase in fertilizer level for both seasons. Significant differences were observed in the iron content only at the very low fertilizer level, which resulted in the highest concentration of forage iron for the long day season. Possibly some level of dilution was affecting the iron concentrations as DMY increased from the very low to the high fertilization levels (Vicente-Chandler et al., 1983). Manganese concentrations were adequate for cattle in both seasons with no difference among the four fertilizer rates.

Hay molybdenum was low in all samples, and considerably less than the toxic level of $6 \mathrm{mg} / \mathrm{kg}$. The average $\mathrm{Cu} / \mathrm{Mo}$ ratio in the forage was greater than 2 to 1 . Miltimore and Masson (1971) suggested that a lower ratio could result in copper deficiency. However, copper concentrations were deficient in relation to cattle requirement, independent of any $\mathrm{Co} / \mathrm{Mo}$ antagonism.

Fertilization of the four grasses studied at the high rate $(3,364 \mathrm{~kg} /$ ha of 15-5-10) resulted in a higher DMY mean than the lower fertilizer applications. The high rate is also recommended over the lower application rates for obtaining the highest hay $\mathrm{CP}$ content. However, during the short-day season, the CP content of hay receiving the highest fertilizer treatment was below the $7 \%$ critical concentration needed by cattle. The variations in the $\mathrm{Ca}, \mathrm{Na}, \mathrm{K}, \mathrm{Fe}$ and $\mathrm{CP}$ content within the different fertilizer treatments suggested the possible use of these parameters as indicators of DMY or fertilization requirement rank. These chemical indicators could thus help in the prediction of levels of fertilizer required on commercial farms with similar soil conditions. However, more research is needed in relation to the practical use of minerals as chemical indicators of hay yield for commercial farms in Puerto Rico.

\section{LITERATURE CITED}

Arroyo-Aguilú, J. A. and J. A. Oporta-Téllez, 1980. Chemical composition and in vitro nutrient digestibility of guinea and merker grass hays. J. Agric. Univ. P.R. 31(3):294-303. 
Fick, K. R., L. R. McDowell, P. H. Miles, N. S. Wilkinson, J. D. Funk and J. H. Conrad, 1979. Methods of Mineral Analysis for Plant and Animal Tissues (2nd edition). Animal Science Department, University of Florida, Gainesville, FL.

Gallaher, R. N., C. O. Weldon and J. G. Frutal, 1975. An aluminum block digester for plant and soil analysis. Proc. Soil Sci. Soc. Amer: 39:803-806.

Gutierrez-Vargas, R., J. A. Arroyo-Aguilú and A. Ramírez-Ortiz, 1978. Voluntary intake, chemical composition and nutrient digestibility of pangolagrass and stargrass hay. J. Agric: Univ. P.R. 29(4):389-98.

McDowell, L. R., 1985. Contribution of tropical forage and soils toward meeting mineral requirements of grazing ruminants, p. 165-166. In: McDowell L. R. (ed). Nutrition of Grazing Ruminants in Warm Climates. Academic Press, New York, NY,

McDowell, L. R., J. H. Conrad and F. G. Hembry, 1993. Minerals for grazing ruminants in tropical regions (2nd edition) Bulletin, University of Florida, Gainesville, FL.

Méndez-Cruz, A. V., N. Corchado-Juarbe and V. Siberio-Torres, 1988. Storage and digestibility, voluntary intake and chemical components of hay of five tropical grasses. J. Agric. Univ. P.R. 72(4):531-543.

Méndez-Cruz, A. V., V. Siberio-Torres, J. Fernández-Van Cleve, E. Fontanet and G. Ramírez-Oliveras, 1988. Yield and nutritive value of hay from five tropical grasses at three harvesting intervals. J. Agric. Univ. P.R. 72(1):109-118.

Miltimore, J. E. and J. L. Masson, 1971. Copper to molybdenum ratio concentrations in ruminant feeds. Can. J. Anim. Sci. 51(1):143-200.

Minson, D. J., 1971. The nutritive value of tropical pastures. J. Aust. Inst. Agric. Sci. 37:255.

Moore, J. E. and G. O. Mott, 1974. Recovery of residual organic matter from an in vitro digestion of forage. J. Dairy Sci. 57:1,258-1,259.

NRC, 1984. Nutrient requirements of domestic animals (No. 4). Nutrient requirements of beef (6th revised edition). National Academy of Sciences, National Research Council, Washington, D.C.

Perkin-Elmer Corp., 1992. Analytical methods for atomic absorption spectrophotometry. Perkin-Elmer, Norwalk, CT.

Perkin-Elmer Corp., 1984. Analytical methods of furnace atomic absorption spectrometry. Perkin-Elmer, Norwalk, CT.

Randel, P. F. and A. V. Mendez-Cruz, 1989. Guía paxa la posible clasificación de henos comerciales de gramíneas. Bol 285. Estación Experimental Agrícola de Puerto Rico.

Technicon Industrial Systems, 1978. Individual/simultaneous determination of crude protein, phosphorus and/or calcium in feeds. Industrial methods No. 605-77 A. Tarrytown, N.Y.

Vicente-Chandler, J., R. Caro-Costas, F. Abruña and S. Silva, 1983. Producción y utilización intensiva de las forrajeras en Puerto Rico. Estación Experimental Agrícola, Río Piedras, Puerto Rico. Bol. 271.

Whetter, P. A., and D. E. Ullrey, 1978. Improved fluorimetric method for determining selenium. J. Assoc. Off. Anal. Chem. 61:927-930. 